\title{
Review
}

\section{Role of Histone Acetylation in Hematological Malignancies}

\author{
Takakazu Higuchi and Mitsuhiro OMINE
}

\begin{abstract}
Remodeling of chromatin structure through the modification of histone acetylation is critical in the regulation of transcription. A variety of hematological malignancies have genetic aberrations associated with mechanisms involved in the regulation of acetylation. For cases in which aberrant acetylation contributes to the development of malignant phenotypes, the restoration of the physiological acetylation pattern is expected to lead to the normal phenotype. This form of differentiation therapy is exemplified by the successful treatment of acute promyelocytic leukemia (APL) with all-trans retinoic acid. This review summarizes hematological malignancies resulting from genetic abnormalities leading to abnormal acetylation patterns and discusses the underlying role of these mechanisms in oncogenesis. Modification of aberrant acetylation patterns may specifically direct malignant cells along differentiation pathways thereby restoring the normal phenotype. This form of treatment is disease-oriented and, because it is designed to repair abnormalities at the molecular level, can be regarded as "molecular target" therapy.
\end{abstract}

Key words : acetylation, histone, leukemia, non-Hodgkin lymphoma

\section{Introduction}

The most common strategy for the treatment of hematological malignancies has been intensive multidrug chemotherapy using cytotoxic drugs aiming for a "total cell kill" or eradication of the malignant cells. Most of these cytotoxic drugs either cause cell death or inhibit the cell cycle and are not selective, affecting normal and malignant cells equally. The first evidence that specific oncogenic molecular events resulting in hematological malignancy can be reversed by clinical intervention was demonstrated by the success of alltrans retinoic acid (ATRA) differentiation therapy of acute promyelocytic leukemia (APL). The molecular basis of APL pathogenesis is aberrant histone acetylation that can be altered with ATRA. ATRA modifies acetylation by acting on the fusion product of specific chromosomal translocations.

Recently, extensive efforts have been made to target molecules involved in oncogenesis, most commonly those involved in cellular signal transduction. These approaches are usually disease-specific and can lead to individualized therapy. Another approach is to target more general events involved in a variety of malignancies, for example, histone acetylation. The remodeling of chromosomal structure by modifications to histone acetylation is critical in the regulation of transcription. Various cytogenetic abnormalities observed in diverse

Division of Hematology, Internal Medicine, Showa University Fujigaoka Hospital, 1-30 Fujigaoka, Aoba-ku, Yokohama 227-8501, Japan. 
hematological malignancies result in aberrant histone acetylation that, in turn, leads to aberrant transcription of genes and the development of malignant phenotypes. Restoration of the acetylation pattern may initiate the differentiation of malignant cells and thereby restore the normal hematological phenotype. This approach is therefore a disease-specific approach based on the molecular mechanisms involved in oncogenesis.

This review describes hematological malignancies with cytogenetic abnormalities involving aberrant histone acetylation and discusses the advantages of treating such malignancies by modulating the acetylation state.

\section{Transcriptional Regulation and Acetylation of Histones}

In the eukaryotic nucleus, DNA winds periodically around histone octamers forming a basic structural unit of chromatin called the nucleosome (Fig. 1, right) ${ }^{1}$. A histone octamer core contains two molecules of each histones, H2A, H2B, H3, and H4. In the nucleosome, DNA is normally transcriptionally inactive. Several mechanisms alter the structure of chromatin and transcriptional activity. Aberration of histone acetylation is one mechanism identified in certain hematological malignancies that leads to abnormal transcription and inhibition of differentiation.

Acetylation of histones is mediated by histone acetyltransferase (HAT) identified in a series of transcriptional coactivators. Histone acetylation usually occurs at lysine residues in the amino terminal of the histone tails (Fig. 1, left). Acetylation alters the electrostatic

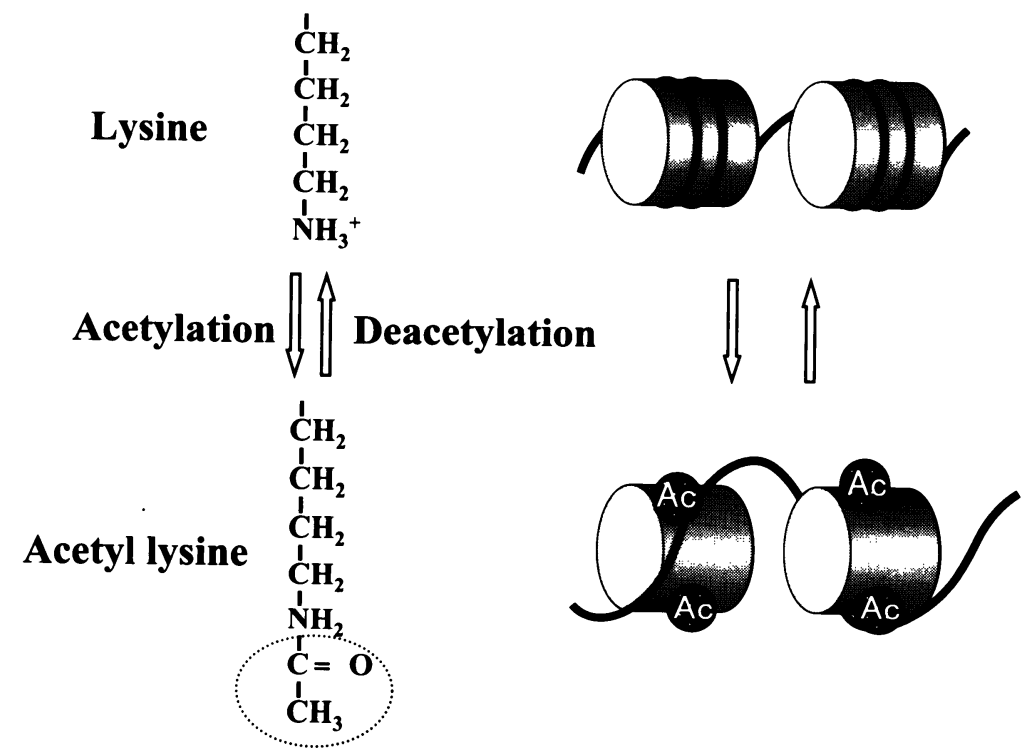

Fig. 1. Transcriptional regulation through acetylation of histones. In the transcriptionally silent state, DNA is wound tightly around core histones, to form the nucleosome structure. Acetylation of histone occurs at lysine residues of histone tails and is mediated by histone acetyltransferase (HAT). Acetylated histones have a decreased affinity to DNA leading to disruption of the nucleosome and initiation of transcription. Acetyl groups are removed by the action of histone deacetylase (HDAC), which restores tightly packed nucleosomes and leads to inhibition of transcription. 
state of the histones thereby decreasing their affinity to DNA and disrupting nucleosomes (Fig. 1. right). Disrupted nucleosomes allow the transcriptional machinery to access to the "relaxed" DNA and to initiate transcription that would otherwise be inhibited ${ }^{2)}$. Acetylation may also facilitate binding of certain transcriptional factors to promoters leading to disruption of the higher order chromatin structure ${ }^{3)}$. Specific histone deacetylase (HDAC) enzymes associated with corepressors remove the acetyl group of acetylated histones leading to inhibition of transcription. A number of families of HAT and three classes of HDAC have been identified and their diverse activities have been determined ${ }^{1)}$.

Modification or remodeling of chromatin is also mediated through ATP hydrolysis by ATP-dependent chromatin-remodeling factors that alter the interaction between DNA and histones and further promote transcription. Methylation at both DNA and protein levels can regulate gene expression and a link between methylation and acetylation is established. Acetylation of non-histone proteins also participates in regulation of transcription. Thus, transcription is regulated in a very intricate and well-balanced fashion and involves acetylation in a major role.

\section{Acute Promyelocytic Leukemia}

APL comprises 10 to $15 \%$ of acute myeloid leukemias and is characterized by the accumulation of cells arrested at the promyelocytic stage of differentiation. APL is the first human malignancy for which differentiation therapy has been clinically proven ${ }^{4)}$.

APL is associated with a chromosomal translocation $t(15 ; 17)$ involving the retinoic acid receptor- $\alpha(\operatorname{RAR} \alpha)$ gene on chromosome $17^{5,6)}$. Most APL cases harbor the translocation $\mathrm{t}(15 ; 17)(\mathrm{q} 22 ; \mathrm{q} 21)$ that fuses the RAR $\alpha$ gene on chromosome 17 to the PML (promyelocytic leukemia) gene on chromosome 15 , while rare cases have genes other than PML as the fusion partner of $\operatorname{RAR}_{\alpha}$ (Table 1$)$.

$\operatorname{RAR} \alpha$ is a member of the nuclear receptor family and regulates the transcription of genes with the retinoic acid responsive element (RARE) in their promoter region by forming a heterodimeric complex with the retinoid $\mathbf{X}$ receptor $(\mathbf{R X R})-\alpha$, which also belongs to the nuclear receptor family (Figs. 2, 3, A $)^{7,8)}$. The $\operatorname{RAR} \alpha-\operatorname{RXR} \alpha$ heterodimer regulates transcription by modulating the acetylation status of core histones as a result of the recruitment of corepressors or coactivators.

RAR $\alpha$ consists of six functional domains (A through F) (Fig. 2). There are two regions that function to stimulate transcription, the ligand-independent activation function (AF)-1 region in the A/B domain and the ligand-dependent AF-2 region in the $\mathrm{E} / \mathrm{F}$ domain $^{9,10)}$. AF-2 associates with coactivators upon binding of the ligand. The $\mathrm{C}$ domain contains a

Table 1. Fusion partners of $\operatorname{RAR}_{\alpha}$ translocation in acute promyelocytic leukemia

\begin{tabular}{lc}
\multicolumn{1}{c}{ Partner Gene } & Breakpoint \\
\hline PML (promyelocytic leukemia) & $15 \mathrm{q} 22$ \\
PLZF (promyelocytic zinc finger) & $11 \mathrm{q} 23$ \\
NPM (Nucleophosmin) & $5 \mathrm{q} 32$ \\
NuMa (Nuclear mitotic apparatus protein) & $11 \mathrm{q} 13$ \\
STAT5 (Signal transducer and activator of transcription 5) & interstitial deletion on 17 \\
\hline
\end{tabular}

$\operatorname{RAR} \alpha$, retinoic acid receptor- $\alpha$ 

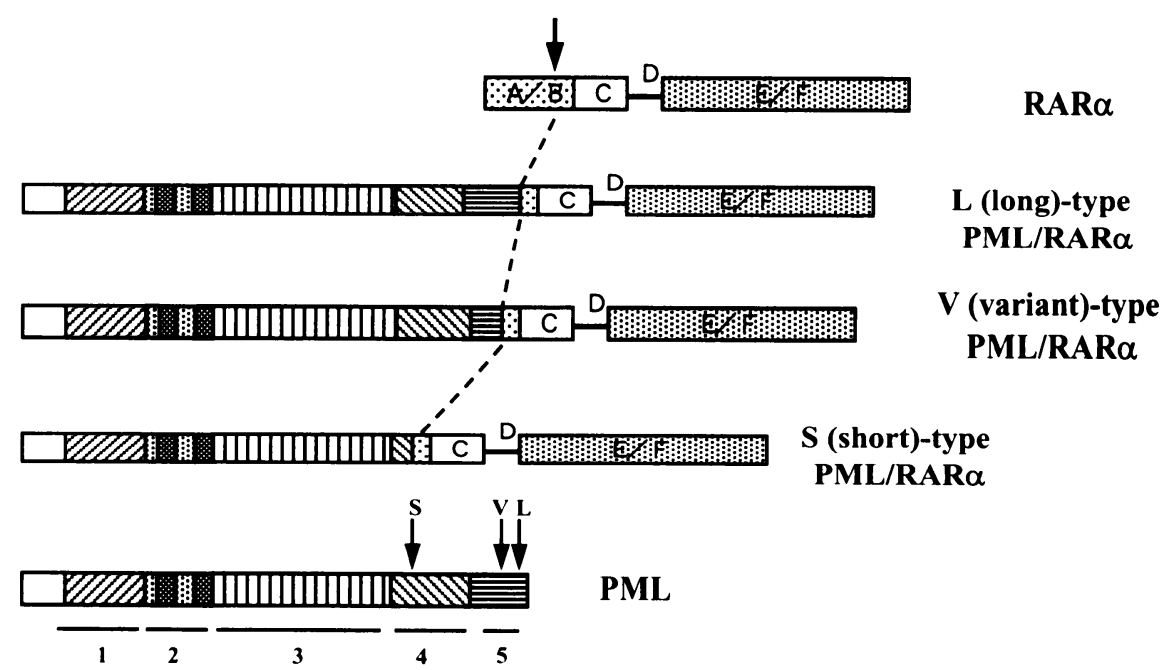

Fig. 2. Structures of RAR $\alpha, P M L$, and PML-RAR $\alpha$ fusion proteins.

RAR $\alpha$ is composed of six domains, A to F. The breakpoint in RAR $\alpha$ observed in APL patients is invariable. PML has five domains and, starting from the $\mathrm{N}$-terminal end, they include, (1) RING-finger, (2) B-box, (3) coiled-coil, (4) nuclear localization signal, and (5) serine- and proline-rich domains. Three different breakpoints are identified in PML resulting in three different PML-RAR $\alpha$ fusion proteins.

DNA-binding domain. The $\mathrm{E}$ domain, in addition to AF-2, has a ligand binding and heterodimerization domain for RXR. Spanning the domains $D$ to $E$ is a CoR box region that binds corepressors ${ }^{11}$.

In the absence of the ligand, the $\operatorname{RAR} \alpha-\operatorname{RXR} \alpha$ heterodimer is bound to $\operatorname{RARE}$ and associated with a corepressor complex consisting of N-CoR (nuclear repressor corepressor) /SMRT (silencing mediator of retinoid- and thyroid-hormone receptor), mSin $3 \mathrm{~A}$ (mammalian Sin3A) and HDAC ${ }^{11,12)}$ (Fig. 3, A). This corepressor complex silences the target genes of $\operatorname{RAR} \alpha$ through the deacetylation of the histones. In the presence of ATRA, ligandbound $\operatorname{RAR} \alpha$ undergoes a conformational change, releasing the corepressor complex and, in turn, recruiting a coactivator complex consisting of CBP (CREB-binding protein)/p300, SRC (steroid receptor-coactivator)-1, P/CAF (p300/CBP-associated factor), each of which possesses HAT activity, and activates the transcription of target genes through the acetylation of histones ${ }^{10,13-16)}$.

Most APL patients have the PML-RAR $\alpha$ fusion protein as a result of the $t(15 ; 17)$ translocation (Fig. 2). The breakpoint in $\operatorname{RAR} \alpha$ is invariable among patients and the domains from $B$ to $F$ are retained in the fusion protein. In contrast, there is a variation of the breakpoints in the PML gene, and three variant forms of PML-RAR $\alpha$ fusion are known ${ }^{17)}$. As there is no major difference in the phenotypes or clinical behavior among the variants, the PML portion in the shortest form (S-type) of the fusions may be critical for the development of $A P L^{18,19)}$. These PML domains contain regions referred to as 1) RING finger, which is required for protein-protein interactions, 2) B-box, which participates in the DNA-binding, and 3) coiled-coil region, which is responsible for homo- and heterodimerization. 
A) Wild-type RAR $\alpha$

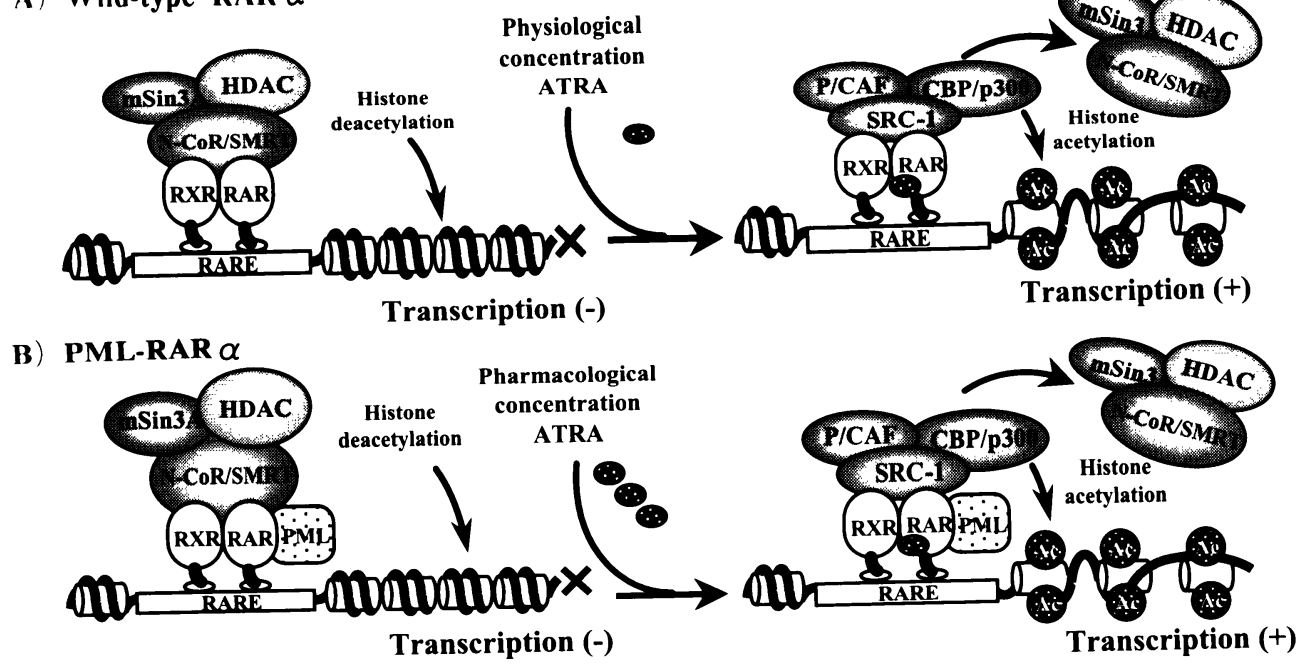

Fig. 3. Transcriptional regulation by wild-type $\operatorname{RAR} \alpha$ and $\operatorname{PML}-\operatorname{RAR} \alpha$.

A) In the absence of ATRA, the wild-type $\operatorname{RAR} \alpha / \operatorname{RXR} \alpha$ heterodimer is associated with the corepressor complex and transcription is repressed. When the physiological concentration of ATRA is present, the corepressor complex is released and, in turn, the heterodimer recruits coactivators and activates transcription through the acetylation of histones. B) PML-RAR $\alpha$ forms a PML-RAR $\alpha / \operatorname{RXR} \alpha$ heterodimer with increased affinity to the corepressor complex and therefore stronger transcriptional repression than wild-type $\operatorname{RAR} \alpha$. As a result, PML-RAR $\alpha$ requires higher than physiological concentrations of ATRA to dissociate the corepressor complex.

The PML-RAR $\alpha$ fusion protein acts in a dominant-negative fashion on wild-type RAR $\alpha$ and suppresses $\operatorname{RAR} \alpha$ regulated transcription ${ }^{20,21)}$. Like wild-type $\operatorname{RAR} \alpha$, the PML-RAR $\alpha$ fusion protein binds to RARE, recruits $\mathrm{N}-\mathrm{CoR} / \mathrm{SMRT}$ corepressors and suppresses transcription (Fig. 3B $)^{12,22-24)}$. In this case, although the PML portion does not bind the corepressors, the formation of the PML-RAR $\alpha$ fusion protein increases the affinity of RAR $\alpha$ to the corepressors via a mechanism not yet understood. Alternatively, the PML-RAR $\alpha$ fusion protein can form a PML-RAR $\alpha /$ PML-RAR $\alpha$ homodimer ${ }^{25)}$. Each PML-RAR $\alpha$ fusion protein retains a corepressor-binding domain of $\operatorname{RAR} \alpha$, resulting in the association of two corepressor complexes and a higher local concentration of the corepressors and stronger transcriptional repression compared to the $\operatorname{RAR} \alpha / \operatorname{RXR} \alpha$ heterodimer.

In the case of wild-type $\operatorname{RAR} \alpha$, the corepressors dissociate from $\operatorname{RAR} \alpha$ in the presence of physiological concentrations of ATRA leading to the recruitment of coactivators and the activation of transcription (Fig. 3, A). In contrast, the corepressors have a stronger binding affinity for the PML-RAR $\alpha$ fusion protein and cannot be released in the presence of physiological concentrations of ATRA, leading to suppression of $\operatorname{RAR} \alpha$ target genes (Fig. 3, B). Higher concentrations of ATRA release the corepressors from the PML-RAR $\alpha$ fusion protein and, through the recruitment of coactivators, activate transcription, thereby relieving the APL blasts from the differentiation-block and facilitating differentiation. ATRA also leads to the degradation of the PML-RAR $\alpha$ fusion protein, contributing further to the progression of APL cell differentiation ${ }^{26-28)}$.

Other mechanisms may participate in the pathogenesis of APL. The PML-RAR $\alpha / R X R \alpha$ 
heterodimer or the PML-RAR $\alpha /$ PML-RAR $\alpha$ homodimer bound to RARE may inhibit the binding of wild-type $\operatorname{RAR} \alpha / \operatorname{RXR} \alpha$ heterodimer to $\operatorname{RARE}$ and impede the transcriptional regulation of genes normally regulated by $\operatorname{RAR}{ }^{29)}$. Alternatively, PML-RAR $\alpha$ may have target genes other than those regulated by wild-type $\operatorname{RAR}_{\alpha}$ and aberrant regulation of these genes may contribute to the development of $\mathrm{APL}^{30)}$. Also, the sequestration of $\mathrm{RXR} \alpha$ by the PML-RAR $\alpha$ fusion protein may result in the depletion of free $\operatorname{RXR} \alpha$ and inhibit the formation of the $\operatorname{RAR} \alpha / \operatorname{RXR} \alpha$ heterodimer ${ }^{29-31)}$.

\section{Acute Leukemia with Aberration Involving AML1 Gene}

Acute myelocytic leukemia with $t(8 ; 21)$

Modulation of the acetylation state of histones may also be involved in other non-APL translocations and contribute to a differentiation-block and leukemogenesis.

The $\mathrm{t}(8 ; 21)$ ( $\mathrm{q} 22 ; \mathrm{q} 22)$ translocation occurs in $40 \%$ of acute myeloid leukemia (AML) with an M2 subtype characterized by differentiation toward neutrophils and a favorable prognosis $^{4)}$. The translocation $t(8 ; 21)$ juxtaposes the AML1 (acute myeloid leukemia 1, or preferably RUNX1) gene on chromosome 21 to ETO (eight-twenty-one or MTG8) gene on chromosome 8, creating a fusion protein AML1/ETO (Fig. 4).

AML1 is a sequence specific DNA-binding protein and activates transcription of target genes via the formation of a heterodimeric complex with core binding factor $\beta$ (CBFB or PEBP $\beta$ ) that enhances the DNA-binding activity of AML1. The heterodimer binds to the TGT/cGGT motif frequently identified in genes expressed in hematopoietic cells (Fig. 5A). The AML1 protein is associated with $\mathrm{CBP} / \mathrm{p} 300$, a coactivator with $\mathrm{HAT}$ activity, and also directly binds $\mathrm{P} / \mathrm{CAF}$ through the $\mathrm{C}$-terminal region to activate target genes ${ }^{32)}$. Impaired hematopoiesis in AML1-knock out mice reinforces the importance of AML1 in normal hematopoiesis ${ }^{33)}$.

The gene sequence for the ETO protein was identified at the breakpoint of the translocation $t(8 ; 21)$. The ETO protein interacts directly with corepressors N-CoR/SMRT and $\mathrm{mSin} 3 \mathrm{~A}$ via zinc-finger motifs located in the $\mathrm{C}$-terminal region and recruits $\mathrm{HD}$ $\mathrm{AC}^{34,35)}$. The $\mathrm{AML1} / \mathrm{ETO}$ fusion protein retains the $\mathrm{N}$-terminal region of $\mathrm{AML1}$, including the Runt homology domain (RHD) and DNA-binding domain, but the transactivation domain is lost and is replaced by nearly all of the ETO protein (Fig. 4). The resulting AML1/ETO fusion protein has the ability to bind to the promoter regions of AML1responsive genes and repress transcription by interaction with corepressors at the ETO portion of the fusion protein ${ }^{36)}$. The AML1/ETO fusion protein competes with wild-type AML1 and suppresses the transcription of AML1-responsive genes important in normal hematopoiesis in a dominant-negative fashion, maintaining histones in the deacetylated state (Fig. 5B). Transcription repression domains are also identified in AML1 and it is postulated that AML1 acts as a repressor of transcription according to cell type, target gene, and the environment ${ }^{37)}$. It is probable that the AML1/ETO fusion protein results in a disturbance of the intricate balance between activation and repression of the genes involved in hematopoiesis thereby leading to impaired hematopoietic cell differentiation.

The leukemogenic potential of AML1/ETO has been demonstrated by several experiments. Heterozygous AML1/ETO knocked-in mice are embryonic lethal with a complete absence of definitive hematopoiesis as seen in the AML1 knock-out mice ${ }^{38)}$ but their fetal livers contain dysplastic multilineage hematopoietic progenitors with high self-renewal capacity ${ }^{38)}$. Also, 


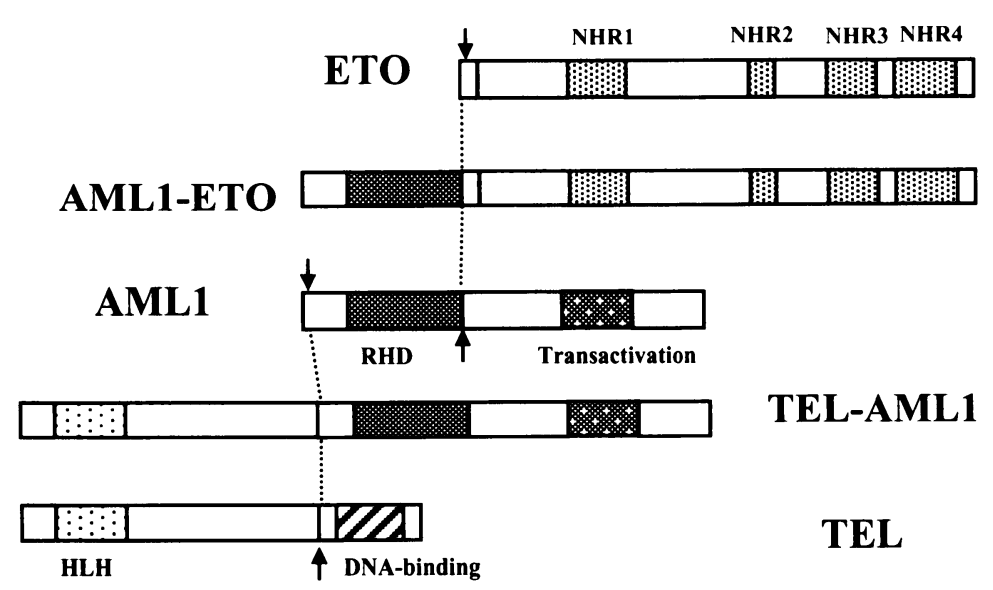

Fig. 4. Structures of AML1, ETO, and TEL proteins and their translocation products. The AML1-ETO fusion protein fuses the N-terminal domain of AML-1, including the Runt homology domain (RHD), to most of the ETO protein. The TEL-AML1 fusion protein fuses the TEL domain, including proteinprotein interaction and corepressor binding sites, and most of the AML protein. NHR, nervy homology region; HLH, helix-loop-helix.

A) AML1

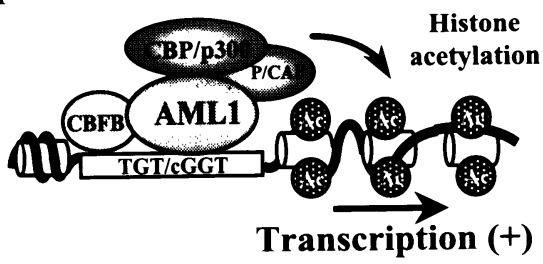

B) AML1-ETO

$\mathbf{t}(8 ; 21)$

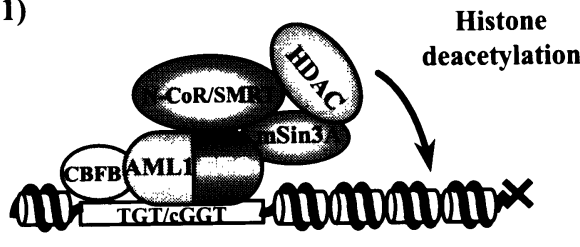

Transcription (-)

Fig. 5. Transcriptional regulation by AML1 and AML1-ETO.

A) AML1 on the AML1-response gene forms a heterodimer with CBFB, associates with a coactivator p300/CBP, and activates the genes involved in normal hematopoiesis through histone acetylation. B) The AML1-ETO fusion protein heterodimerizes with CBFB and binds to the AML-1 response gene, it then recruits the corepressors $\mathrm{N}-\mathrm{CoR} /$ SMRT, mSin3A and HDAC at the ETO portion resulting in transcriptional repression. 


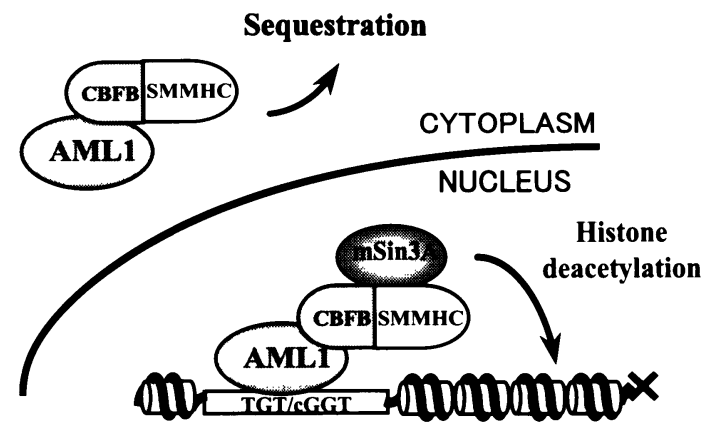

Transcription (-)

Fig. 6. Dominant negative repression of AML1-responsive genes by the fusion product of inv (16). The fusion product of inv (16), CBFB-SMMHC, forms a heterodimer with AML1 and sequesters AML1 in the cytoplasm. In the nucleus, the CBFBSMMHC/AML1 heterodimer associates with AML1-responsive genes and represses transcription by recruiting the $\mathrm{mSin} 3 \mathrm{~A}$ corepressor.

murine bone marrow progenitor cells transduced with AML1/ETO obtain increased self-renewal capacity and immature phenotypes ${ }^{38)}$. Antisense oligonucleotides against AML1/ ETO reduce cell proliferation rate and promote the differentiation of AML cells harboring the translocation $t(8 ; 21)^{39)}$. HDAC inhibitors partially inhibit ETO-mediated transcriptional repression and induce the differentiation of cells harboring $t(8 ; 21)^{40)}$. These observations show that, although AML1/ETO alone is not sufficient for the development of full-blown leukemia, it is responsible for the proliferation and differentiation block in AML associated with $\mathrm{t}(8 ; 21)$.

Acute myelomonocytic leukemia with inv (16)

The inv (16) (p13; q22) is associated with the AML subtype M4Eo, which has a favorable prognosis. The inv (16) disrupts the CBFB gene on 16q22 close to the 3' end of the coding region and smooth muscle myosin heavy chain (SMMHC, or MYH11) gene on 16p13, resulting in the CBFB-SMMHC fusion gene, which contains most of the CBFB coding region and the 3' portion of $\mathrm{SMMHC}^{41)}$.

The CBFB-SMMHC fusion protein acts as a transcriptional repressor of AML1-mediated genes, thereby inhibiting the normal function of AML1 in controlling hematopoiesis. The CBFB-SMMHC fusion protein retains the ability to interact with AML1 to form a heterodimer (Fig. 6). The resulting CBFB-SMMHC/AML1 heterodimers are retained in the cytoplasm where they sequester $\mathrm{AML1}^{42,43)}$. The CBFB-SMMHC/AML1 heterodimer also forms a ternary complex with the mSin3A corepressor and inhibits the function of $A M L 1^{44)}$. The C-terminal portion of SMMHC in the CBFB-SMMHC fusion protein may also suppress AML1-mediated transcription by sequestering AML1 and/or acting as a dominant negative repressor of AML1 function ${ }^{44)}$. 


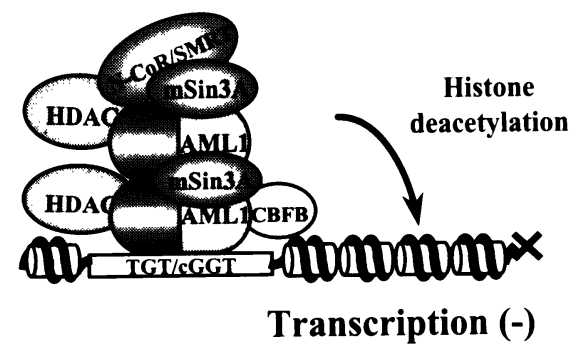

Fig. 7. Transcriptional repression by the TEL-AML1 fusion protein. The TEL-AML1 fusion protein forms homodimers at the TEL portion and represses the transcription of AML1-responsive genes by recruiting corepressors and HDAC.

Pediatric lymphoblastic leukemia with $t(12 ; 21)$

Another chromosomal translocation involving AML1, t $(12 ; 21)(\mathrm{p} 13 ; \mathrm{q} 22)$, is observed in childhood B-lineage acute lymphoblastic leukemia (ALL) with favorable prognosis ${ }^{45)}$. This translocation fuses the 5' portion of the TEL (Translocation-Ets-Leukemia, or ETV6) gene on $12 \mathrm{q} 13$ and most of the AML1 gene ${ }^{45,46)}$ (Fig. 4). Although often unidentified by conventional karyotype study, this fusion gene is observed in about $25 \%$ of childhood B-lineage ALL ${ }^{45)}$. The TEL protein is a sequence-specific DNA-binding protein and acts as a transcription repressor ${ }^{47)}$. TEL recruits the corepressors mSin 3 and $\mathrm{N}-\mathrm{CoR}$ and also interacts with HDAC via the $\mathrm{N}$-terminal portion retained in the TEL-AML1 fusion protein ${ }^{48,49)}$. The TEL-AML1 fusion protein forms homodimer via the TEL portion ${ }^{45)}$ and represses transcription of genes regulated by $\mathrm{AML1}^{47)}$. Two of nine transgenic mice expressing TEL-AML1 developed ALL with one being of T-lineage ${ }^{50)}$. Therefore, the TEL-AML1 fusion protein is not always sufficient to induce ALL, with additional "hits" probably required to develop the characteristics usually observed in the clinical setting.

\section{Other leukemias with aberrations of AML1}

In addition to recurrent translocations involving the AML1 gene, other abnormalities affecting the AML1 gene are recognized. Contrary to the translocations, $t(8 ; 21)$, inv $(16)$, and $\mathrm{t}(12 ; 21)$, which associate with a favorable prognosis, $t(3 ; 21)(\mathrm{q} 26 ; \mathrm{q} 22)$ is observed in cases of blast crisis in chronic myelogenous leukemia and leukemias transformed from myelodysplastic syndromes (MDS), both of which are derived from abnormalities at the hematopoietic stem cell level and associated with a poor prognosis. The $t(3 ; 21)$ (q26; q22) fuses the 5' portion of the AML1 gene and whole coding region of the EVI-1 (ecotropic viral integration site 1) gene on 3 q26 creating AML1-EVI-1 fusion gene. The AML1-EVI-1 fusion protein is a dominant negative repressor of AML1 and blocks the function of AML1. EVI-1 also contributes to leukemogenesis by inhibiting transforming growth factor (TGF)- $\beta$. TGF- $\beta$ inhibits cellular proliferation via intracellular signal transducers known as Smad factors. AML1-EVI-1 interacts with and inhibits Smad3 and antagonizes the anti-proliferative action of TGF- $\beta$. The EVI-1 portion of the AML1-EVI-1 fusion protein interacts with CtBP (C-terminal binding protein), which in turn associates 
with HDAC. The HDAC inhibitor represses the inhibitory effect of EVI-1 on TGF- $\beta$ signaling. Thus, inhibition of Smad3 acetylation may be involved in the inhibitory function of TGF- $\beta^{51)}$. AML1-EVI-1 also blocks the transactivation function of AML1 by interacting with CtBP and HDAC ${ }^{52)}$. Evi-1 is also associated with CBP and P/CAF, both of which have HAT activity ${ }^{53)}$.

Another translocation involving AML1 is reported in therapy-related AML/MDS and hypoplastic MDS. AML1 is broken in the $t(16 ; 21)(\mathrm{q} 24 ; \mathrm{q} 22)$ at the same intron observed in $\mathrm{t}(8 ; 21)$ and fused to MTG16 (myeloid translocation gene on chromosome 16) ${ }^{54}$. In addition to the translocations involving the AML1 gene, mutations within AML1 gene are observed in AML and MDS $^{55,56)}$. These mutations are located within the Runt homology domain and were observed in eight out of 160 leukemia patients. It is possible that these mutations result in aberrant AML1 function and contribute to the development of leukemia and $\mathrm{MDS}^{55)}$.

\section{Other Leukemias Possibly Involving Aberrant Acetylation of Histones}

An increased understanding of the mechanism of transcriptional regulation, combined with investigations of genes involved in various chromosomal abnormalities, has lead to the identification of several chromosomal translocations that involve genes encoding transcriptional coactivators. It is postulated that aberrant acetylation of genes essential for normal development of hematopoietic cells is responsible for the development of hematological malignancies (Table 2).

Coactivator CBP is located at chromosome $16 \mathrm{p} 13$ and is involved in translocations $\mathrm{t}(8$; 16) $(\mathrm{p} 11 ; \mathrm{p} 13)^{57,58)}, \mathrm{t}(11 ; 16)(\mathrm{q} 23 ; \mathrm{p} 13)^{59-61)}$, and $\mathrm{t}(10 ; 16)(\mathrm{q} 22 ; \mathrm{p} 13)^{62,63)}$, creating fusion genes MOZ (monocyte leukemia zinc finger protein)/CBP, MLL (mixed lineage leukemia)/CBP, and MORF (monocytic leukemia zinc finger protein-related factor)/CBP, respectively. The $t(8 ; 16)$ is observed predominantly in patients with AML M4/M5 subtypes and is postulated to be involved in the maturation block at the granulo-monocytic stage $^{57,58)}$. By comparison, the $t(11 ; 16)$ is observed in therapy-related MDS or leukemia, suggesting that hematopoiesis is dysregulated at a more immature stage ${ }^{59,60)}$. A link between $\mathrm{t}(10 ; 16)$ and a specific form of leukemia has not been made. The fusion

Table 2. Chromosomal translocations observed in acute leukemias involving coactivators

\begin{tabular}{cc}
\hline Translocation & Resulting Fusion Protein \\
\hline $\mathrm{t}(8 ; 16)(\mathrm{p} 11 ; \mathrm{p} \mathrm{13})$ & $\mathrm{MOZ} / \mathrm{CBP}$ \\
$\mathrm{t}(11 ; 16)(\mathrm{q} 23 ; \mathrm{p} \mathrm{13})$ & $\mathrm{MLL} / \mathrm{CBP}$ \\
$\mathrm{t}(10 ; 16)(\mathrm{q} 22 ; \mathrm{p} \mathrm{13})$ & $\mathrm{MORF} / \mathrm{CBP}, \mathrm{CBP} / \mathrm{MORF}$ \\
$\mathrm{t}(11 ; 22)(\mathrm{q} 23 ; \mathrm{q} \mathrm{13})$ & $\mathrm{MLL} / \mathrm{p} 300$ \\
inv $(8)(\mathrm{p} 11 ; \mathrm{q} \mathrm{13})$ & $\mathrm{MOZ} / \mathrm{TIF} 2$ \\
$\mathrm{t}(8 ; 22)(\mathrm{p} 11 ; \mathrm{q} \mathrm{13})$ & $\mathrm{MOZ} / \mathrm{p} 300$ \\
\hline
\end{tabular}

MOZ, monocyte leukemia zinc finger protein; CBP, CREBbinding protein; MLL, mixed lineage leukemia; MORF, monocytic leukemia zinc finger protein-related factor; TIF2, transcriptional intermediary factor 2 


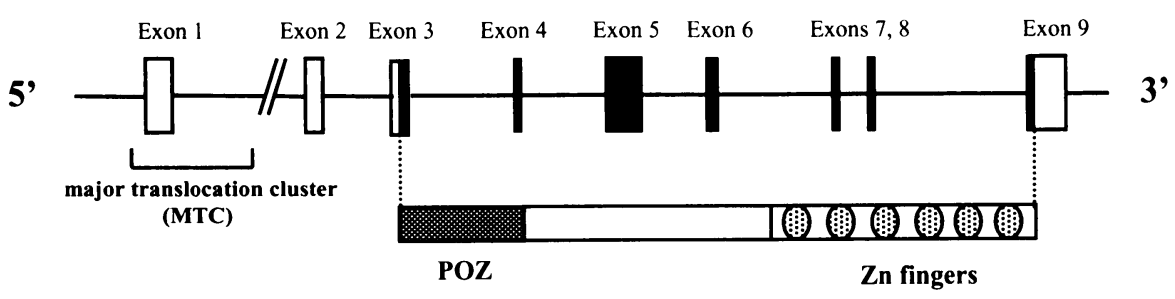

Fig. 8. Structure of the BCL-6 gene and protein. The breakpoints of the BCL-6 gene are clustered at the 5'-flanking region, the first exon, and the first intron (MTC). The coding exons are expressed with filled boxes. POZ (pox virus and zinc finger) mediates self-interaction and protein-protein interactions and is the corepressor-binding site. C-terminal zinc fingers are DNA-binding sites.

products of these translocations retain the putative DNA-interacting domains of $\mathrm{MOZ}$, MLL, and MORF, respectively, and the HAT domain of $\mathrm{CBP}^{59-62)}$. MOZ and MORF also have putative HAT activity ${ }^{57,62,64)}$. On the contrary, the transcription repression domain of MLL in MLL/CBP is fused to $\mathrm{CBP}^{53,59)}$. Thus, deranged transcriptional regulation caused by the aberrant remodeling of chromosomes as a result of aberrantly regulated acetylation of histones may contribute to maturation arrest and leukemogenesis in cases with these translocations.

Other chromosomal translocations leading to leukemia that involve aberrations of acetylation coactivator genes include $\mathrm{t}(11 ; 22)(\mathrm{q} 23 ; \mathrm{q} 13)$, which fuses the MLL gene to the coactivator $\mathrm{p} 300$ gene $^{65)}$ and inv $(8)(\mathrm{p} 11 ; \mathrm{q} 13)^{66,67)}$ and $\mathrm{t}(8 ; 22)(\mathrm{p} 11 ; \mathrm{q} 13)^{68)}$ which fuse the MOZ gene to TIF2 (transcriptional intermediary factor 2) and p300 genes, respectively. Disruption of the normal pattern of histone acetylation is thought to mediate leukemogenesis in these cases.

It is expected that inhibitors of HAT may revert the maturation block by repressing aberrant histone acetylation thus allowing cells to differentiate. This would be particularly relevant in cases involving $\mathrm{t}(8 ; 16)$ in which a maturation block occurs at a specific stage in cell differentiation. Where the maturation block is less defined, suppression of HAT activity may enhance the ability of leukemic cells to restore normal growth and differentiation programs.

\section{Non-Hodgkin Lymphomas with Aberrations of BCL-6 Gene}

Abnormal regulation of transcription due to deranged acetylation of histones may be involved in the oncogenesis of non-Hodgkin lymphomas (NHL) due to mutations in the BCL-6 (B cell lymphoma 6, or LAZ3) gene.

The BCL-6 gene is located at chromosome $3 q 27$ and the protein product is normally expressed in mature B cells in the germinal center of lymph nodes and is thought to control certain stages of B cell differentiation ${ }^{69-71)}$. The BCL-6 protein contains a C-terminal Krüppel-like zinc fingers involved in DNA-binding and an N-terminal POZ (pox virus and zinc finger) domain, which mediates self-interaction and protein-protein interaction (Fig. 8). It binds DNA through the C-terminal zinc fingers and recruits the $\mathrm{N}-\mathrm{CoR} / \mathrm{SMRT} / \mathrm{mSin} 3 \mathrm{~A} /$ HDAC complex at the $\mathrm{N}$-terminal $\mathrm{POZ}$ domain and acts as a transcriptional repressor of genes with a core BCL-6 binding sequence ${ }^{72-74)}$. Histone deacetylase inhibitors inhibit the 
transcriptional repression by BCL- $6^{73)}$. Thus, it is assumed that BCL-6 regulates B cell differentiation by differentially silencing genes expressed during B cell development through suppression of histone acetylation. BCL-6 also interacts with the corepressor B-CoR (BCL-6 interacting corepressor), which is regulated via HDAC, at the POZ domain ${ }^{75)}$.

The BCL-6 gene is rearranged in about $40 \%$ of diffuse large cell and $10 \%$ of follicular lymphomas $^{76)}$. While the translocation partners of BCL-6 are variable, the breakpoints of the BCL-6 gene are located at the 5'-flanking region, the first exon, or the first intron, replacing the promoter region with regulatory elements from the translocation partners. In addition, point mutations in the 5'-noncoding region of the BCL-6 gene are found in a large number of cases of diffuse large cell and follicular lymphomas ${ }^{77)}$. Abnormal chromatin remodeling and transcription as a result of these genetic aberrations may contribute to the development of lymphomas. The regulatory function of the BCL-6 protein is modulated by acetylation of the protein-protein interaction domain ${ }^{78)}$. The acetylated BCL-6 protein prevents the association of the corepressor complex leading to inhibition of the transcriptional repressive function of BCL-6. The acetylation site in this domain is critical for BCL-6-mediated transformation leading to the assumption that aberrant acetylation of this protein plays a role in oncogenesis.

\section{Conclusion}

Aberrant acetylation of histones is involved in the pathogenesis of a wide variety of hematological malignancies. The notion that physiological development can be restored upon correction of acetylation patterns is exemplified by the success of differentiation therapy of APL by ATRA. A return to normal transcription of specific genes, as in the case of APL, combined with correction of the global acetylation pattern, may allow malignant cells to differentiate normally providing a positive clinical outcome. This strategy is disease-specific and may be regarded as "molecular target" therapy as it targets intracellular mechanisms involved in oncogenesis. This type of therapy is in contrast to the conventional chemotherapy, which is a "total cell kill" approach.

\section{References}

1) Marks P, Rifkind RA, Richon VM, Breslow R, Miller T and Kelly WK : Histone deacetylases and cancer : causes and therapies. Nat Rev Cancer 1 : 194-202 (2001)

2) Redner RL, Wang J and Liu JM: Chromatin remodeling and leukemia: new therapeutic paradigms. Blood $94: 417-428$ (1999)

3) Luo RX and Dean DC: Chromatin remodeling and transcriptional regulation. J Natl Cancer Inst 91 : 12881294 (1999)

4) Jaffe ES, Harris NL, Stein H and Vardiman JW (Eds): Pathology and Genetics of Tumours and Haematopoietic and Lymphoid Tissues. IARC Press, Lyon, France (2001)

5) de Thé $H$, Chomienne $C$, Lanotte $M$, Degos $L$ and Dejean $A$ : The $t(15 ; 17)$ translocation of acute promyelocytic leukaemia fuses retinoic acid receptor gene to a novel transcribed locus. Nature 347: 558-561 (1990)

6) Kakizuka A, Miller WH Jr, Umesono K, Warrel RP Jr, Frankel SR, Murty VV, Dmitrovsky E and Evans RM : Chromosomal translocation $\mathrm{t}(15 ; 17)$ in human acute promyelocytic leukemia fuses $\operatorname{RAR} \alpha$ with a novel putative transcriptional factor, PML. Cell $66: 663-674$ (1991)

7) Minucci S, Leid M, Toyama R, Saint-Jeannet JP, Peterson VJ, Horn V, Ishmael JE, Bhattacharyya N, Dey A, Dawid IB and Ozato $\mathrm{K}$ : Retinoid X receptor (RXR) within the RXR-retinoic acid receptor heterodimer binds its ligand and enhances retinoid-dependent gene expression. Mol Cell Biol 17 : 644-655 (1997)

8) Forman BM, Umesono $\mathrm{K}$, Chen $\mathrm{J}$ and Evans $\mathrm{RM}$ : Unique response pathways are established by allosteric interactions among nuclear hormone receptors. Cell 81 : 541-550 (1995) 
9) Nagpal S, Friant S, Nakshatri $H$ and Chambon P: RARs and RXRs: evidence for two autonomous transactivation functions (AF-1 and $\mathrm{AF}-2)$ and heterodimerization in vivo. EMBO J $12: 2349-2360$ (1993)

10) Durand B, Saunders M, Gaudon C, Roy B, Losson R and Chambon P: Activation function 2 (AF-2) of retinoic acid receptor and 9-cis retinoic acid receptor: presence of a conserved autonomous constitutive activating domain and influence of the nature of the response element on AF-2 activity. EMBO J 13:53705382 (1994)

11) Kurokawa R, Söderström M, Hörlein A, Halachmi S, Brown M, Rosenfeld MG and Glass CK : Polarity-specific activities of retinoic acid receptors determined by a co-repressor. Nature $377: 451-454$ (1995)

12) Hong SH, David G, Wong CW, Dejean A and Privalsky ML: SMRT corepressor interacts with PLZF and with the PML-retinoic acid receptor $\alpha(\operatorname{RAR} \alpha)$ and $\operatorname{PLZF-RAR} \alpha$ oncoproteins associated with acute promyelocytic leukemia. Proc Natl Acad Sci USA 94 : 9028-9033 (1997)

13) Darimont BD, Wagner RL, Apriletti JW, Stallcup MR, Kushner PJ, Baxter JD, Fletterick RJ, Yamamoto KR : Structure and specificity of nuclear receptor-coactivator interactions. Genes Dev 12 : 3343-3356 (1998)

14) Dilworth FJ, Fromental-Ramain C, Remboutsika E, Benecke A and Chambon P : Ligand-dependent activation of transcription in vitro by retinoic acid receptor $\alpha$ /retinoid $\mathbf{X}$ receptor $\alpha$ heterodimers that mimics transactivation by retinoids in vivo. Proc Natl Acad Sci USA 96 : 1995-2000 (1999)

15) Westin S, Kurokawa R, Nolte RT, Wisely GB, McInerney EM, Rose DW, Milburn MV, Rosenfeld MG and Glass CK : Interactions controlling the assembly of nuclear-receptor heterodimers and co-activators. Nature 395 : 199-202 (1998)

16) Blanco JCG, Minucci S, Lu J, Yang XJ, Walker KK, Chen H, Evans RM, Nakatani Y and Ozato K : The histone acetylase PCAF is a nuclear receptor coactivator. Genes Dev 12 : 1638-1651 (1998)

17) Pandolfi PP, Alcalay M, Fagioli M, Zangrilli D, Mencarelli A, Diverio D, Biondi A, Lo Coco F, Rambaldi A, Grignani F, Rochette-Egly C, Gaube MP Chambon P and Pelicci PG : Genomic variability and alternative splicing generate multiple PML/RAR $\alpha$ transcripts that encode aberrant PML proteins and PML/RAR $\alpha$ isoforms in acute promyelocytic leukaemia. EMBO J 11 : 1397-1407 (1992)

18) Gallagher RE, Willman CL, Slack JL, Andersen JW, Li YP, Viswanatha D, Bloomfield CD, Appelbaum FR, Schiffer CA, Tallman MS and Wiernik PH: Association of PML-RAR $\alpha$ fusion mRNA type with pretreatment hematologic characteristics but not treatment outcome in acute promyelocytic leukemia: an intergroup molecular study. Blood 90 : 1656-1663 (1997)

19) Fukutani H, Naoe T, Ohno R, Yoshida H, Miyawaki S, Shimazaki C, Miyake T, Nakayama Y, Kobayashi H, Goto S, Takeshita A, Kobayashi S, Kato Y, Shiraishi K, Sasada M, Ohtake S, Murakami H, Kobayashi M, Endo N, Shindo H, Matsushita K, Hasegawa S, Tsuji K, Ueda Y, Tominaga N, Furuya H. Inoue Y, Takeuchi J, Morishita $\mathbf{H}$ and Iida $\mathrm{H}$ : Isoforms of PML-retinoic acid receptor alpha fused transcripts affect neither clinical features of acute promyelocytic leukemia nor prognosis after treatment with all-trans retinoic acid. Leukemia 9 : 1478-1482 (1995)

20) Kastner P, Perez A, Lutz Y, Rochette-Egly C, Gaub MP, Durand B, Lanotte M, Berger R and Chambon P: Structure, localization and transcriptional properties of two classes of retinoic acid receptor $\alpha$ fusion proteins in acute promyelocytic leukemia (APL): structural similarities with a new family of oncoproteins. EMBO J 11 : 629-642 (1992)

21) Daniel MT, Koken M, Romagné O, Barbey S, Bazarbachi A, Stadler M, Guillemin MC, Degos L, Chomienne $\mathrm{C}$ and de The H: PML protein expression in hematopoietic and acute promyelocytic leukemia cells. Blood 82 : $1858-1867$ (1993)

22) Lin RJ, Nagy L, Inoue S, Shao W, Miller WH Jr and Evans RM : Role of the histone deacetylase complex in acute promyelocytic leukaemia. Nature 391 : 811-814 (1998)

23) Grignani F, De Matteis S, Nervi C, Tomassoni L, Gelmetti V, Cioce M, Fanelli M, Ruthardt M, Ferrara FF, Zamir I, Seiser C, Grignani F, Lazar MA, Minucci S and Pelicci PG: Fusion proteins of the retinoic acid receptor- $\alpha$ recruit histone deacetylase in promyelocytic leukaemia. Nature 391 : 815-818 (1998)

24) Guidez F, Ivins S, Zhu J, Söderström M, Waxman S and Zelent A : Reduced retinoic acid-sensitivities of nuclear receptor corepressor binding to PML- and PLZF-RAR $\alpha$ underlie molecular pathogenesis and treatment of acute promyelocytic leukemia. Blood 91 : 2634-2642 (1998)

25) Lin RJ and Evans RM : Acquisition of oncogenic potential by RAR chimeras in acute promyelocytic leukemia through formation of homodimers. Mol Cell $5: 821-830$ (2000)

26) Koken MH, Puvion-Dutilleul F, Guillemin MC, Viron A, Linares-Cruz G, Stuurman N, de Jong L, Szostecki C, Calvo F, Chomienne C, Degos L, Puvion E and de The $\mathrm{H}$ : The $\mathrm{t}(15 ; 17)$ translocation alters a nuclear body in a retinoic acid-reversible fashion. EMBO $J 13: 1073-1083$ (1994)

27) Raelson JV, Nervi C, Rosenauer A, Benedetti L, Monczak Y, Pearson M, Pelicci PG and Miller WH Jr: The PML/RAR $\alpha$ oncoprotein is a direct molecular target of retinoic acid in acute promyelocytic leukemia cells Blood 88 : 2826-2832 (1996) 
28) Yoshida H, Kitamura K, Tanaka K, Omura S, Miyazaki T, Hachiya T, Ohno R and Naoe T: Accelerated degradation of PML-retinoic acid receptor $\alpha$ (PML-RARA) oncoprotein by all-trans-retinoic acid in acute promyelocytic leukemia : possible role of the proteasome pathway. Cancer Res 56 : 2945-2948 (1996)

29) Jasen JH, Mahfoudi A, Rambaud S, Lavau C, Wahli W and Dejean A: Multimeric complexes of the PML-retinoic acid receptor $\alpha$ fusion protein in acute promyelocytic leukemia cells and interference with retinoid and peroxisome-proliferator signaling pathways. Proc Natl Acad Sci USA 92 : 7401-7405 (1995)

30) Perez A, Kastner P, Sethi S, Lutz Y, Reibel C and Chambon P: PMLRAR homodimers: distinct DNA binding properties and heteromeric interactions with RXR. EMBO J 12 : 3171-3182 (1993)

31) Rousselot P, Hardas B, Patel A, Guidez F, Gäken J, Castaigne S, Dejean A, de Thé H, Degos L, Farzaneh $F$ and Chomienne $C$ : The PML-RAR $\alpha$ gene product of the $t(15 ; 17)$ translocation inhibits retinoic acid-induced granulocytic differentiation and mediated transactivation in human myeloid cells. Oncogene 9 : 545-551 (1994)

32) Kitabayashi I, Yokoyama A, Shimizu $\mathbf{K}$ and Ohki $\mathbf{M}$ : Interaction and functional cooperation of the leukemia-associated factors AML1 and p300 in myeloid cell differentiation. EMBO J $17: 2994-3004$ (1998)

33) Okuda T, van Deursen J, Hiebert SW, Grosveld G and Downing JR: AML1, the target of multiple chromosomal translocations in human leukemia, is essential for normal fetal liver hematopoiesis. Cell 84 : 321-330 (1996)

34) Wang J, Hoshino T, Redner RL, Kajigaya $\mathbf{S}$ and Liu JM : ETO, function partner in $t(8 ; 21)$ acute myeloid leukemia, represses transcription by interaction with the human N-CoR/mSin3/HDAC1 complex. Proc Natl Acad Sci USA 95 : 10860-10865 (1998)

35) Lutterbach B, Westendorf JJ, Linggi B, Patten A, Moniwa M, Davie JR, Huynh KD, Bardwell VJ, Lavinsky RM, Rosenfeld MG, Glass C, Seto E and Hiebert SW : ETO, a target of $t(8 ; 21)$ in acute leukemia, interacts with the N-CoR and mSin3 co-repressors. Mol Cell Biol 18 : 7176-7184 (1998)

36) Gelmetti V, Zhang J, Fanelli M, Minucci S, Pelicci PG, Lazar MA : Aberrant recruitment of the nuclear receptor corepressor-histone deacetylase complex by the acute myeloid leukemia fusion partner ETO. Mol Cell Biol 18 : 7185-7191 (1998)

37) Lutterbach B, Westendorf JJ, Linggi B, Issac S, Seto E and Hiebert SW : A mechanism of repression by acute myeloid leukemia-1, the target of multiple chromosomal translocations in acute leukemia. $J$ Biol Chem 275 : 651-656 (2000)

38) Okuda T, Cai Z, Yang S, Lenny N, Lyu C, van Deursen JM, Harada H and Downing JR : Expression of a knocked-in AML1-ETO leukemia gene inhibits the establishment of normal definitive hematopoiesis and directly generates dysplastic hematopoietic progenitors. Blood 91 : 3134-3143 (1998)

39) Sakakura C, Yamaguchi-Iwai Y, Satake M, Bae SC, Takahashi A, Ogawa E, Hagiwara A, Takahashi T, Murakami A, Makino K, Nakagawa T, Kamada $\mathrm{N}$ and Ito $\mathrm{Y}$ : Growth inhibition and induction of differentiation of $\mathrm{t}(8 ; 21)$ acute myeloid leukemia cells by the DNA-binding domain of PEBP2 and the A ML1/MTG8 (ETO)-specific antisense oligonucleotide. Proc Natl Acad Sci USA 91 : 11723-11727 (1994)

40) Wang J, Saunthararajah Y, Redner RL and Liu JM : Inhibitors of histone deacetylase relieve ETO-mediated repression and induce differentiation of AML1-ETO leukemia cells. Cancer Res 59: 2766-2769 (1999)

41) Liu P, Tarlé SA, Hajra A, Claxton DF, Marlton P, Freedman M, Siciliano MJ and Collins FS : Fusion between transcription factor $\mathrm{CBF} \beta / \mathrm{PEBP} 2 \beta$ and a myosin heavy chain in acute myeloid leukemia. Science 261 : 1041-1044 (1993)

42) Adya N, Stacy T, Speck NA and Liu PP: The leukemic protein core binding factor $\beta$ (CBF $\beta$ )-smooth-mus cle myosin heavy chain sequesters $\mathrm{CBF} \alpha 2$ into cytoskeletal filaments and aggregates. Mol Cell Biol 18 : 7432-7443 (1998)

43) Kanno Y, Kanno T, Sakakura C, Bae SC and Ito Y: Cytoplasmic sequestration of the polyomavirus enhancer binding protein $2(\mathrm{PEBP} 2) /$ core binding factor $\alpha(\mathrm{CBF} \alpha)$ subunit by the leukemia-related PEBP2/CBF $\beta-\mathrm{S}$ MMHC fusion protein inhibits PEBP2/CBF-mediated transactivation. Mol Cell Biol 18 : 4252-4261 (1998)

44) Lutterbach B, Hou Y, Durst KL and Hiebert SW: The inv (16) encodes an acute myeloid leukemia 1 transcriptional corepressor. Proc Natl Acad Sci USA 96 : 12822-12827 (1999)

45) McLean TW, Ringold S, Neuberg D, Stegmaier K, Tantravahi R, Ritz J, Koeffler HP, Takeuchi S, Janssen JWG, Seriu T, Bartram CR, Sallan SE, Gilliland DG and Golub TR : TEL/AML-1 dimerizes and is associated with a favorable outcome in childhood acute lymphoblastic leukemia. Blood 88 : 4252-4258 (1996)

46) Romana SP, Mauchauffe M, Le Coniat M, Chumakov I, Le Paslier D, Berger R and Bernard OA: The $t$ ( 12 ; 21) of acute lymphoblastic leukemia results in a tel-AML1 gene fusion. Blood 85 : 3662-3670 (1995)

47) Lopez RG, Carron C, Oury C, Gardellin P, Bernard O and Ghysdael J: TEL is a sequence-specific transcriptional repressor. J Biol Chem 274 : 30132-30138 (1999)

48) Wang $L$ and Hiebert SW: TEL contacts multiple co-repressors and specifically associates with histone deacetylase-3. Oncogene $20: 3716-3725$ (2001) 
49) Guidez F, Petrie K, Ford AM, Lu H, Bennett CA, MacGregor A, Hannemann J, Ito Y, Ghysdael J, Greaves M, Wiedemann LM and Zelent A : Recruitment of the nuclear receptor corepressor N-CoR by the TEL moiety of the childhood leukemia-associated TEL-AML1 oncoprotein. Blood $96: 2557-2561$ (2000)

50) Bernardin F, Yang Y, Cleaves R, Zahurak M, Cheng L, Civin CI and Friedman AD : TEL-AML1, expressed from $t(12 ; 21)$ in human acute lymphocytic leukemia, induces acute leukemia in mice. Cancer Res 62 : 3904-3908 (2002)

51) Izutsu K, Kurokawa M, Imai Y, Maki K, Mitani K and Hirai H : The corepressor CtBP interacts with Evi-1 to repress transforming growth factor $\beta$ signaling. Blood $97: 2815-2822$ (2001)

52) Izutsu K, Kurokawa M, Imai Y, Ichikawa M, Asai T, Maki K, Mitani K and Hirai H: The $t(3 ; 21)$ fusion product, AML1/Evi-1 blocks AML1-induced transactivation by recruiting CtBP. Oncogene 21: 2695-2703 (2002)

53) Chakraborty S, Senyuk V, Sitailo S, Chi Y and Nucifora G: Interaction of EVI1 with cAMP-responsive element-binding protein-binding protein $(\mathrm{CBP})$ and $\mathrm{p} 300 / \mathrm{CBP}$-associated factor $(\mathrm{P} / \mathrm{CAF})$ results in reversible acetylation of EVI1 and in co-localization in nuclear speckles. J Biol Chem 276 : 44936-44943 (2001)

54) Gamou T, Kitamura E, Hosoda F, Shimizu K, Shinohara K, Hayashi Y, Nagase T, Yokoyama Y and Ohki $\mathrm{M}$ : The partner gene of $A M L 1$ in $\mathrm{t}(16 ; 21)$ myeloid malignancies is a novel member of the MTG8 (ETO) family. Blood 91 : 4028-4037 (1998)

55) Osato M, Asou N, Abdalla E, Hoshino K, Yamasaki H, Okubo T, Suzushima H, Takatsuki K, Kanno T, Shigesada $\mathrm{K}$ and Ito $\mathrm{Y}$ : Biallelic and heterozygous point mutations in the Runt domain of the $A M L 1 / P E B P 2=B$ gene associated with myeloblastic leukemias. Blood 93 : 1817-1824 (1999)

56) Imai Y, Kurokawa M, Izutsu K, Hangaishi A, Takeuchi K, Maki K, Ogawa S, Chiba S, Mitani K and Hirai H : Mutations of the $A M L 1$ gene in myelodysplastic syndrome and their functional implications in leukemogenesis. Blood $96: 3154-3160$ (2000)

57) Borrow J, Stanton VP Jr, Andresen JM, Becher R, Behm FG, Chaganti RSK, Civin CI, Disteche C, Dubé I, Frischauf AM, Horsman D, Mitelman F, Volinia S, Watmore AE and Housman DE: The translocation $\mathbf{t}$ (8; 16) (p11; p13) of acute myeloid leukaemia fuses a putative acetyltransferase to the CREB-binding protein. Nat Genet $14: 33-41$ (1996)

58) Giles RH, Dauwerse JG, Higgins C, Petrij F, Wessels JW, Beverstock GC, Döhner H, Jotterand-Bellomo M, Falkenburg JH, Slater RM, van Ommen GJ, Hagemeijer A, van der Reijden BA and Breuning MH : Detection of $C B P$ rearrangements in acute myelogenous leukemia with $t(8 ; 16)$. Leukemia $11: 2087-2096$ (1997)

59) Taki T, Sako M, Tsuchida $M$ and Hayashi $Y$ : The $t(11 ; 16)$ (q23; p13) translocation in myelodysplastic syndrome fuses the $M L L$ gene to the CBP gene. Blood $89: 3945-3950$ (1997)

60) Rowley JD, Reshmi S, Sobulo O, Musvee T, Anastasi J, Raimondi S, Schneider NR, Barredo JC, Cantu ES, Schlegelberger B, Behm F, Doggett NA, Borrow J and Zeleznik-Le N : All patients with the $t(11 ; 16)$ (q23; p13.3) that involves $M L L$ and $C B P$ have treatment-related hematologic disorders. Blood 90 : $535-541$ (1997)

61 ) Sobulo OM, Borrow J, Tomek R, Reshmi S, Harden A, Schlegelberger B, Housman D, Doggett NA, Rowley JD and Zeleznik-Le NJ : MLL is fused to CBP, a histone acetyltransferase, in therapy-related acute myeloid leukemia with a t $(11 ; 16)$ (q23;p13.3). Proc Natl Acad Sci USA 94 : 8732-8737 (1997)

62) Panagopoulos I, Fioretos T, Isaksson M, Samuelsson U, Billström R, Strömbeck B, Mitelman F and Johansson $\mathrm{B}$ : Fusion of the MORF and CBP genes in acute myeloid leukemia with the $\mathrm{t}(10 ; 16)(\mathrm{q} 22 ; \mathrm{p} 13)$. Hum Mol Genet 10 : 395-404 (2001)

63) Kojima K, Kaneda K, Yoshida C, Dansako H, Fujii N, Yano T, Shinagawa K, Yasukawa M and Fujita S : A novel fusion variant of the $M O R F$ and $C B P$ genes detected in therapy-related myelodysplastic syndrome with $\mathrm{t}(10 ; 16)$ (q22; p13). Br J Haematol $120: 271-273$ (2003)

64) Champagne $N$, Pelletier $N$ and Yang $\mathrm{XJ}$ : The monocytic leukemia zinc finger protein MOZ is a histone acetyltransferase. Oncogene 20 : 404-409 (2001)

65) Ida K, Kitabayashi I, Taki T, Taniwaki M, Noro K, Yamamoto M, Ohki M and Hayashi Y: Adenoviral E1A-associated protein $\mathrm{p} 300$ is involved in acute myeloid leukemia with $\mathrm{t}(11 ; 22)$ ( $\mathrm{q} 23 ; \mathrm{q} 13)$. Blood 90 : 4699-4704 (1997)

66) Carapeti M, Aguiar RC, Goldman JM and Cross NC: A novel fusion between $M O Z$ and the nuclear receptor coactivator TIF2 in acute myeloid leukemia. Blood $91: 3127-3133$ (1998)

67) Liang J, Prouty L, Williams BJ, Dayton MA and Blanchard KL: Acute mixed lineage leukemia with an inv (8) (p1lq13) resulting in fusion of the genes for MOZ and TIF2. Blood 92 : 2118-2122 (1998)

68) Kitabayashi I, Aikawa Y, Yokoyama A, Hosoda F, Nagai M, Kakazu N, Abe T and Ohki M: Fusion of $\mathrm{MOZ}$ and $\mathrm{p} 300$ histone acetyltransferases in acute monocytic leukemia with a $\mathrm{t}(8 ; 22)(\mathrm{p} 11 ; \mathrm{q} 13)$ chromosome translocation. Leukemia $15: 89-94$ (2001)

69) Ye BH, Lista F, Lo Coco F, Knowles DM, Offit K, Chaganti RS, Dalla-Favera R: Alterations of a zinc finger-encoding gene, $B C L-6$, in diffuse large-cell lymphoma. Science 262 : 747-750 (1993) 
70) Fukuda T, Yoshida T, Okada S, Hatano M, Miki T, Ishibashi K, Okabe S, Koseki H, Hirosawa S, Taniguchi M, Miyasaka $\mathbf{N}$ and Tokuhisa T: Disruption of the Bcl6 gene results in an impaired germinal center formation. J Exp Med 186 : 439-448 (1997)

71) Dent AL, Shaffer AL, Yu X, Allman D and Staudt LM : Control of inflammation, cytokine expression, and germinal center formation by BCL-6. Science 276 : 589-592 (1997)

72) Dhordain P, Albagli O, Lin RJ, Ansieau S, Quief S, Leutz A, Kerckaert JP, Evans RM and Leprince D : Corepressor SMRT binds the BTB/POZ repressing domain of the LAZ3/BCL6 oncoprotein. Proc Natl Acad Sci USA 94 : 10762-10767 (1997)

73) Dhordain P, Lin RJ, Quief S, Lantoine D, Kerckaert JP, Evans RM and Albagli O: The LAZ3 (BCL-6) oncoprotein recruits a SMRT/mSIN3A/histone deacetylase containing complex to mediate transcriptional repression. Nucleic Acid Res 26 : 4645-4651 (1998)

74) Huynh KD and Bardwell VJ : The BCL-6 POZ domain and other POZ domains interact with the co-repressors N-CoR and SMRT. Oncogene 17 : 2473-2484 (1998)

75) Huynh KD, Fischle W, Verdin E and Bardwell VJ : BCoR, a novel corepressor involved in BCL-6 repression. Genes Dev 14 : 1810-1823 (2000)

76) Ohno $\mathrm{H}$ and Fukuhara S : Significance of rearrangement of the BCL6 gene in B-cell lymphoid neoplasms. Leuk Lymphoma 27 : 53-63 (1997)

77) Capello D, Vitolo U, Pasqualucci L, Quattrone S, Migliaretti G, Fassone L, Ariatti C, Vivenza D, Gloghini A, Pastore C, Lanza C, Nomdedeu J, Botto B, Freilone R, Buonaiuto D, Zagonel V, Gallo E, Palestro G, Saglio G, Dalla-Favera R, Carbone A and Gaidano G : Disruption and pattern of BCL-6 mutations throughout the spectrum of B-cell neoplasia. Blood $95: 651-659$ (2000)

78) Bereshchenko OR, Gu W and Dalla-Favera R: Acetylation inactivates the transcriptional repressor BCL6. Nat Genet 32 : 606-613 (2002)

[Received November 21, 2003 : Accepted December 15, 2003] 